\title{
Vitreous estrogen levels in patients with an idiopathic macular hole
}

This article was published in the following Dove Press journal:

Clinical Ophthalmology

20 March 2015

Number of times this article has been viewed

\author{
Naoki Inokuchi' \\ Tsunehiko Ikeda ${ }^{2}$ \\ Kimitoshi Nakamura ${ }^{3}$ \\ Seita Morishita ${ }^{2}$ \\ Masanori Fukumoto 2 \\ Teruyo Kida ${ }^{2}$ \\ Hidehiro Oku² \\ 'Inokuchi Eye Clinic, Suita-City Osaka, \\ Japan; ${ }^{2}$ Department of Ophthalmology, \\ Osaka Medical College, Takatsuki-City, \\ Osaka, Japan; ${ }^{3}$ Nakamura Eye Clinic, \\ Matsumoto-City, Nagano, Japan
}

Correspondence: Tsunehiko lkeda Department of Ophthalmology, Osaka Medical College, 2-7 Daigaku-machi, Takatsuki, Osaka 569-8686, Japan

$\mathrm{Tel}+8 \mathrm{I} 726846434$

Fax +81726820995

Email tikeda@poh.osaka-med.ac.jp
Purpose: Estrogen, a female hormone, activates collagenase and might be associated with the pathogenesis of vitreoretinal collagen fiber disease. The purpose of the present study was to investigate the vitreous levels of estrone (E1) and estradiol (E2) in subjects with an idiopathic macular hole (IMH).

Methods: Vitreous samples were obtained from ten female patients with an IMH and from nine female patients with other retinal diseases (six with rhegmatogenous retinal detachment and three with age-related macular degeneration) as a control at the time of vitreous surgery. E1 and E2 levels in the vitreous samples were then determined using the Coat-A-Count ${ }^{\mathbb{R}}$ Estradiol Radioimmunoassay (RIA) Kit and the DSL-70 Estrone RIA Kit, respectively.

Results: The mean vitreous levels of E1 and E2 in the subjects with IMH were $1.83 \pm 2.00 \mathrm{pg} / \mathrm{mL}$ and $7.03 \pm 2.97 \mathrm{pg} / \mathrm{mL}$, respectively, whereas in the control subjects they were $2.42 \pm 1.25 \mathrm{pg} / \mathrm{mL}$ and $4.90 \pm 2.90 \mathrm{pg} / \mathrm{mL}$, respectively. Thus, the vitreous E2 levels in the subjects with IMH were significantly higher than in the controls $(P<0.05)$

Conclusion: The findings of this study suggest that $\mathrm{E} 2$ might be associated with the pathogenesis of IMH, but further investigation is needed to elucidate that association.

Keywords: estradiol, estrone, idiopathic macular hole, vitreous surgery, radioimmunoassay

\section{Introduction}

Idiopathic full-thickness macular hole (IMH) is an important cause of poor vision in the elderly that affects predominantly women older than 60 years. Kishi et al reported that tangential traction, which appears to originate exclusively in the premacular vitreous cortex that forms the posterior wall of the premacular liquefied pocket, causes IMHs. Although it is accepted that vitreoretinal traction is an important local factor in the development of an IMH, the systemic risk factors of IMH remain unclear.

Estrogen has many effects on various tissues, such as bone and the cardiovascular system, in addition to the genitals, through classical nuclear receptors and cellular membrane receptors. ${ }^{2-11}$ Estrogen is also known to be associated with the growth of central nerve fibers, and estrogen receptors are reportedly present in the retina. ${ }^{12,13}$ The incidence of IMHs is higher in females, and a high incidence of systemic estrogen therapy has been reported in IMH patients. ${ }^{14,15}$ However, other studies have reported no association with estrogen exposure. ${ }^{16}$ Thus, a possible association between IMH and estrogen remains controversial.

Estrogen reportedly increases the biosynthesis of hyaluronic acid in the skin of mice. ${ }^{17}$ Estrogen activates collagenase and also reportedly has an effect on collagenase production in the cervix of guinea pigs. ${ }^{18}$ If the metabolic change of estrogen after menopause affects ocular collagen metabolism, it might consequently induce constriction of the posterior vitreous membrane and macular hole. To elucidate the 
association between estrogen and IMHs, we investigated vitreous estrogen levels in IMH patients.

\section{Methods}

\section{Subjects}

In this study, ten eyes of ten female patients (age, $62.3 \pm 6.18$ years) undergoing a vitrectomy for an IMH were examined. As a control, nine eyes of nine female patients (mean age, 62.9 \pm 12.3 years) undergoing a vitrectomy for retinal detachment (six patients) and age-related macular degeneration (three patients) were examined.

\section{Sample preparation}

Pure vitreous samples $(0.5 \sim 1.0 \mathrm{~mL})$ were obtained from each patient before initiating intraocular infusion at the time of vitreous surgery. All samples were frozen at $80^{\circ} \mathrm{C}$ immediately after being obtained.

\section{Radioimmunoassay}

The levels of estradiol (E2) and estrone (E1) in each sample were determined, using the Coat-A-CountR Estradiol Radioimmunoassay (RIA) Kit (Diagnostic Products Corporation, Los Angeles, CA, USA) and the DSL-70 Estrone RIA Kit (Diagnostic Systems Laboratories, Inc., Webster, TX, USA), respectively. This measuring system also included the interference tests.

\section{Statistical analysis}

Comparisons between the groups were made using the Mann-Whitney $U$-test, and a $P$-value $<0.05$ was considered statistically significant.

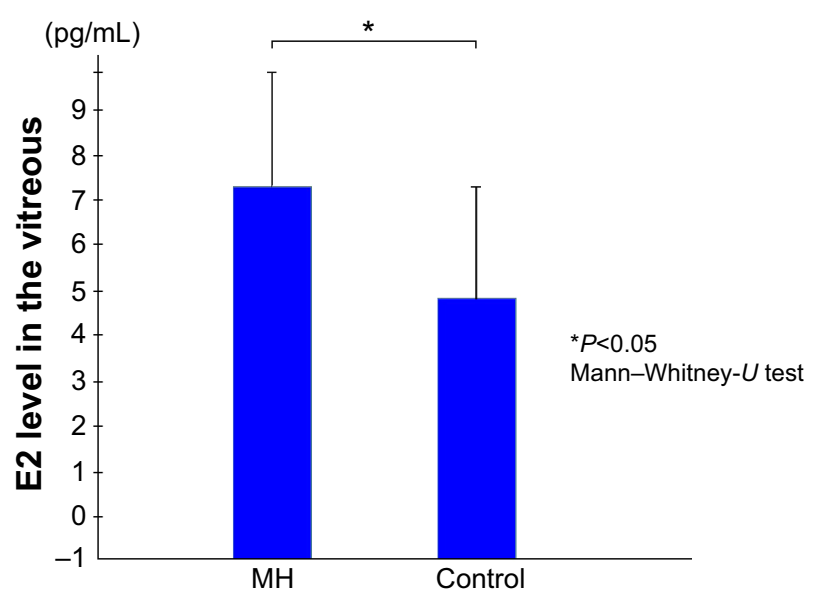

Figure I Vitreous E2 levels.

Note: The mean E2 levels in the vitreous samples obtained from the patients with an idiopathic macular hole were significantly higher than that in the vitreous samples obtained from the controls.

Abbreviations: E2, estradiol; $\mathrm{MH}$, patients with an idiopathic macular hole.

\section{Results}

The mean E2 levels in the vitreous samples obtained from the IMH patients was $7.03 \pm 2.97 \mathrm{pg} / \mathrm{mL}$, which was significantly higher than the level in the vitreous samples obtained from the controls $(4.90 \pm 2.90 \mathrm{pg} / \mathrm{mL} ; P<0.05)$ (Figure 1). The mean $\mathrm{E} 1$ level in the vitreous samples obtained from the IMH patients was $1.83 \pm 2.00 \mathrm{pg} / \mathrm{mL}$, which was not significantly different from that in the vitreous samples obtained from the controls (2.42 $\pm 1.25 \mathrm{pg} / \mathrm{mL}$ ) (Figure 2).

\section{Discussion}

In postmenopausal women, the primary source of estrogen is the adrenal gland, which secretes dehydroepiandrosterone. Dehydroepiandrosterone is converted by steroidogenic enzymes to estrogens in peripheral tissues. ${ }^{9,19}$ Estrogen readily passes through the blood-retinal barrier, and vitreous estrogen is known to be transported from the adrenal gland via blood circulation. In contrast, abundant P450 aromatase is reportedly detectable in the retina of goldfish. ${ }^{20,21}$ Androstenedione is converted to estrogen by $\mathrm{P} 450$ aromatase. ${ }^{22,23}$ If P450 aromatase is expressed in the human eye, local production of estrogen may be the result of an alternating supply source. The findings of this present study show that in patients with an IMH, vitreous E2 levels were higher than E1 levels. E2 is believed to be converted from E1 by 17- $\beta$ hydroxy-dehydrogenase in the eye. This is the first report that evaluated vitreous estrogen levels in patients with an IMH. However, to elucidate the local metabolism of estrogen, further experimental studies will be needed.

E2 exerts the strongest biological activity among the various natural estrogens (E1, E2, and Estriol). Estrogen receptors have a strong affinity for estrogen, which is known to be biologically active even at extremely low levels, and they have reportedly been detected in the retina. ${ }^{12}$ In the present

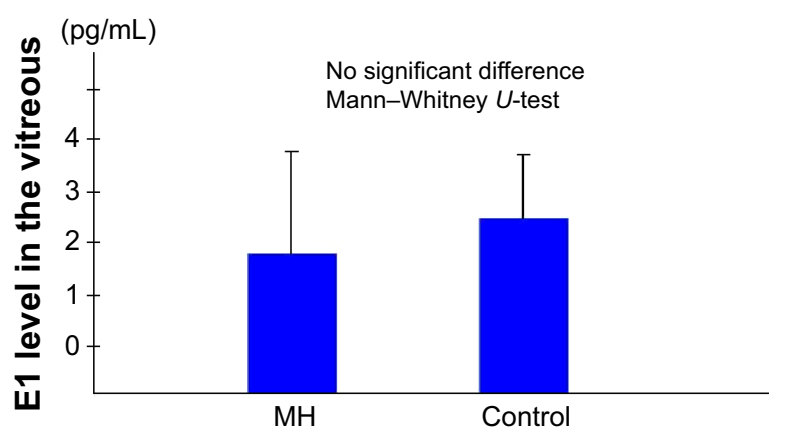

Figure 2 Vitreous EI levels.

Note: The mean EI level in the vitreous samples obtained from the patients with an idiopathic macular hole was not significantly different from that in the vitreous samples obtained from the controls.

Abbreviations: $\mathrm{EI}$, estrone; $\mathrm{MH}$, patients with an idiopathic macular hole. 
study, the observed vitreous E2 levels in the IMH patients were considered more than adequate for biological activity. Vitreous E2 is suggested to have some effect on the eye. Contraction of the posterior vitreous membrane is considered to be one of the steps in the pathogenesis of IMHs. To the best of our knowledge, the effect of estrogen on the vitreous membrane has not yet been elucidated. Previous studies have shown that estrogen has an effect on collagen metabolism and hyaluronic acid production in the skin, ${ }^{16,17}$ and it is believed to have effects on the posterior vitreous membrane. However, those effects have yet to be identified.

Another pathogenesis to clarify the association between estrogen and IMH is related to chymase, a serine protease. Previous studies have reported that chymase converts angiotensin I to angiotensin II; converts latent transforming growth factor 1 to active transforming growth factor 1 , which cleaves procollagen to produce collagen type IV; facilitates collagen degradation by activating matrix metalloproteinase, a catabolic enzyme of extracellular matrix; and inactivates tissue inhibitor of metalloproteinase, a matrix metalloproteinase inhibitor. ${ }^{24,25}$ In addition, chymase is reportedly involved in the degradation of type VI collagen. ${ }^{26}$ Therefore, chymase may be involved in the onset of IMH formation through the production and degradation of collagen.

We previously investigated chymase involvement in the onset of IMH formation, as well as the effects of chymase on monkey eyes and cultured Muller cells. ${ }^{27,28}$ Interestingly, chymase activity in the vitreous humor from IMH patients is the most activated among the vitreoretinal diseases. ${ }^{27}$ Moreover, thickening of the posterior hyaloid membrane and some apoptotic cells were found in the macula of the chymase-treated monkey eyes. These findings suggest that increased chymase activity may result in IMH onset.

Chymase is produced by mast cells, and mast cells have been reported to be involved in tissue fibrosis and neovascularization. ${ }^{29}$ In the eye, mast cells are reportedly present in the choroid, ciliary body, conjunctiva, and sclera. ${ }^{30}$ Nicovani et al reported the presence of estrogen receptors in vascular mast cells and a possible genomic effect of estrogens on the expression of mast cell mediators such as chymase, tumor necrosis factor alpha, nitric oxide synthase, and interleukin $10 .{ }^{31}$ These data illustrate that estrogen can directly modify vascular mast cell activity.

Furthermore, there might be two possibilities that explain the high concentrations of E2 in IMH patients. The first possibility is that pro-inflammatory cytokines such as interleukin 1, tumor necrosis factor alpha, and interleukin 6 are known to disrupt the normal activity of steroidogenic enzymes and promote the aromatization of testosterone to E2. In fact, some previous studies have reported that these proinflammatory cytokines were significantly higher in the vitreous of proliferative diabetic retinopathy and proliferative vitreoretinopathy. ${ }^{32,33}$ In this study, we did not investigate the concentration of these proinflammatory cytokines; however, that possibility should be taken into consideration.

The second possibility is the effects by glucuronidation. Glucuronidation is reportedly the major pathway for estrogen inactivation in humans, ${ }^{9,19}$ and the results shown in that study were altered by glucuronidated E2 and E1. In this study, we did not measure glucuronidated E2 and E1, so further investigation is necessary to confirm this point.

In conclusion, one of the limitations of this current investigation is that it was conducted as a pilot study because of the small number of subjects involved. Further investigation and considerations are necessary to elucidate the association between estrogen and the pathogenesis of IMHs.

\section{Acknowledgment}

We thank John Bush for reviewing the manuscript.

\section{Disclosure}

The authors report no conflicts of interest in this work.

\section{References}

1. Kishi S, Hagimura N, Shimizu K. The role of the premacular liquefied pocket and premacular vitreous cortex in idiopathic macular hole development. Am J Ophthalmol. 1996;122(5):622-628.

2. Colburn P, Buonassisi V. Estrogen-binding sites in endothelial cell cultures. Science. 1978;201(4358):817-819

3. Stampfer MJ, Colditz GA, Willett WC, et al. Postmenopausal estrogen therapy and cardiovascular disease. Ten-year follow-up from the nurses' health study. N Engl J Med. 1991;325(11):756-762.

4. Orimo A, Inoue S, Ikegami A, et al. Vascular smooth muscle cells as target for estrogen. Biochem Biophys Res Commun. 1993; 195(2):730-736.

5. Walsh BW, Schiff I, Rosner B, Greenberg L, Ravnikar V, Sacks FM. Effects of postmenopausal estrogen replacement on the concentrations and metabolism of plasma lipoproteins. $N$ Engl $J$ Med. 1991;325(17):1196-1204

6. Smith EP, Boyd J, Frank GR, et al. Estrogen resistance caused by a mutation in the estrogen-receptor gene in a man. $N$ Engl $J$ Med. 1994;331(16):1056-1061.

7. Wickelgren I. Estrogen stakes claim to cognition. Science. 1997; 276(5313):675-678

8. Tang MX, Jacobs D, Stern Y, et al. Effect of oestrogen during menopause on risk and age at onset of Alzheimer's disease. Lancet. 1996; 348(9025):429-432.

9. Labrie F. DHEA, important source of sex steroids in men and even more in women. Prog Brain Res. 2010;182:97-148.

10. Kacker R, Traish AM, Morgentaler A. Estrogens in men: clinical implications for sexual function and the treatment of testosterone deficiency. $J$ Sex Med. 2012;9(6):1681-1696.

11. Vrtačnik P, Ostanek B, Mencej-Bedrač S, Marc J. The many faces of estrogen signaling. Biochem Med (Zagreb). 2014;24(3):329-342. 
12. Toran-Allerand CD, Miranda RC, Bentham WD, et al. Estrogen receptors colocalize with low-affinity nerve growth factor receptors in cholinergic neurons of the basal forebrain. Proc Natl Acad Sci US A. 1992;89(10):4668-4672.

13. Kobayashi K, Kobayashi H, Ueda M, Honda Y. Estrogen receptor expression in bovine and rat retinas. Invest Ophthalmol Vis Sci. 1998;39(11):2105-2110.

14. McDonnell PJ, Fine SL, Hillis AI. Clinical features of idiopathic macular cysts and holes. Am J Ophthalmol. 1982;93(6):777-786.

15. James M, Feman SS. Macular holes. Albrecht Von Graefes Arch Klin Exp Ophthalmol. 1980;215(1):59-63.

16. The Eye Disease Case-Control Study Group. Risk factors for idiopathic macular holes. Am J Ophthalmol. 1994;118(6):754-761.

17. Uzuka M, Nakajima K, Ohta S, Mori Y. The mechanism of estrogeninduced increase in hyaluronic acid biosynthesis, with special reference to estrogen receptor in the mouse skin. Biochim Biophys Acta. 1980;627(2):199-206.

18. Rajabi MR, Solomon S, Poole AR. Activation of protein kinase C stimulates collagenase production by cultured cells of the cervix of the pregnant guinea pig. Am J Obstet Gynecol. 1992;167(1):194-200.

19. Luu-The V, Labrie F. The intracrine sex steroid biosynthesis pathways. Prog Brain Res. 2010;181:177-192.

20. Gelinas D, Callard GV. Immunocytochemical and biochemical evidence for aromatase in neurons of the retina, optic tectum and retinotectal pathways in goldfish. J Neuroendocrinol. 1993;5(6):635-641.

21. Callard GV, Drygas M, Gelinas D. Molecular and cellular physiology of aromatase in the brain and retina. J Steroid Biochem Mol Biol. 1993;44(4-6):541-547.

22. Simpson E, Rubin G, Clyne C, et al. Local estrogen biosynthesis in males and females. Endocr Relat Cancer. 1999;6(2):131-137.

23. Bulun SE, Zeitoun K, Sasano H, Simpson ER. Aromatase in aging women. Semin Reprod Endocrinol. 1999;17(4):349-358.
24. Johnson JL, Jackson CL, Angelini GD, George SJ. Activation of matrixdegrading metalloproteinases by mast cell proteases in atherosclerotic plaques. Arterioscler Thromb Vasc Biol. 1998;18(11):1707-1715.

25. Frank BT, Rossall JC, Caughey GH, Fang KC. Mast cell tissue inhibitor of metalloproteinase-1 is cleaved and inactivated extracellularly by alpha-chymase. J Immunol. 2001;166(4):2783-2792.

26. Kielty CM, Lees M, Shuttleworth CA, Woolley D. Catabolism of intact type VI collagen microfibrils: susceptibility to degradation by serine proteinases. Biochem Biophys Res Commun. 1993; 191(3):1230-1236.

27. Maruichi M, Oku H, Takai S, et al. Measurement of activities in two different angiotensin II generating systems, chymase and angiotensinconverting enzyme, in the vitreous fluid of vitreoretinal diseases: a possible involvement of chymase in the pathogenesis of macular hole patients. Curr Eye Res. 2004;29(4-5):321-325.

28. Sugiyama T, Katsumura K, Nakamura K, et al. Effects of chymase on the macular region in monkeys and porcine muller cells: probable involvement of chymase in the onset of idiopathic macular holes. Ophthalmic Res. 2006;38(4):201-208.

29. Qu Z, Liebler JM, Powers MR, et al. Mast cells are a major source of basic fibroblast growth factor in chronic inflammation and cutaneous hemangioma. Am J Pathol. 1995;147(3):564-573.

30. May CA. Mast cell heterogeneity in the human uvea. Histochem Cell Biol. 1999;112(5):381-386.

31. Nicovani S, Rudolph MI. Estrogen receptors in mast cells from arterial walls. Biocell. 2002;26(1):15-24.

32. Suzuki Y, Nakazawa M, Suzuki K, Yamazaki H, Miyagawa Y. Expression profiles of cytokines and chemokines in vitreous fluid in diabetic retinopathy and central retinal vein occlusion. Jpn J Ophthalmol. 2011;55(3):256-263.
Clinical Ophthalmology

\section{Publish your work in this journal}

Clinical Ophthalmology is an international, peer-reviewed journal covering all subspecialties within ophthalmology. Key topics include: Optometry; Visual science; Pharmacology and drug therapy in eye diseases; Basic Sciences; Primary and Secondary eye care; Patient Safety and Quality of Care Improvements. This journal is indexed on Submit your manuscript here: http://www.dovepress.com/clinical-ophthalmology-journal

\section{Dovepress}

PubMed Central and CAS, and is the official journal of The Society of Clinical Ophthalmology (SCO). The manuscript management system is completely online and includes a very quick and fair peer-review system, which is all easy to use. Visit http://www.dovepress.com/ testimonials.php to read real quotes from published authors. 